University of Nebraska - Lincoln

DigitalCommons@University of Nebraska - Lincoln

1997

\title{
Correlation of Late-Pleistocene Lake-Level Oscillations in Mono Lake, California, with North Atlantic Climate Events
}

\author{
Larry Benson \\ University of Colorado at Boulder, great.basin666@gmail.com \\ Steve P. Lund \\ University of Southern California, slund@usc.edu \\ James W. Burdett \\ Cornell University \\ Michaele Kashgarian \\ Lawrence Livermore National Laboratory \\ Timothy P. Rose \\ Lawrence Livermore National Laboratory
}

See next page for additional authors

Follow this and additional works at: https://digitalcommons.unl.edu/usgsstaffpub

Part of the Geology Commons, Oceanography and Atmospheric Sciences and Meteorology Commons, Other Earth Sciences Commons, and the Other Environmental Sciences Commons

Benson, Larry; Lund, Steve P.; Burdett, James W.; Kashgarian, Michaele; Rose, Timothy P.; Smoot, Joseph P.; and Schwartz, Martha, "Correlation of Late-Pleistocene Lake-Level Oscillations in Mono Lake, California, with North Atlantic Climate Events" (1997). USGS Staff -- Published Research. 796.

https://digitalcommons.unl.edu/usgsstaffpub/796

This Article is brought to you for free and open access by the US Geological Survey at DigitalCommons@University of Nebraska - Lincoln. It has been accepted for inclusion in USGS Staff -- Published Research by an authorized administrator of DigitalCommons@University of Nebraska - Lincoln. 


\section{Authors}

Larry Benson, Steve P. Lund, James W. Burdett, Michaele Kashgarian, Timothy P. Rose, Joseph P. Smoot, and Martha Schwartz 


\title{
Correlation of Late-Pleistocene Lake-Level Oscillations in Mono Lake, California, with North Atlantic Climate Events
}

\author{
Larry V. Benson \\ U.S. Geological Survey, 3215 Marine Street, Boulder, Colorado 80303-1066 \\ Steve P. Lund \\ Department of Earth Sciences, University of Southern California, Los Angeles, California 90089 \\ James W. Burdett \\ Cornell Laboratory for Stable Isotope Analysis, 125 Boyce Thompson Institute, Tower Road, Cornell University, Ithaca, New York 14583 \\ Michaele Kashgarian and Timothy P. Rose \\ Lawrence Livermore National Laboratory, P.O. Box 808, Livermore, California 94550 \\ Joseph P. Smoot \\ U.S. Geological Survey, MS 955, Reston, Virginia 22092 \\ and \\ Martha Schwartz \\ Department of Earth Sciences, University of Southern California, Los Angeles, California 90089
}

Received April 17, 1997

\begin{abstract}
Oxygen-18 $\left({ }^{18} \mathrm{O}\right)$ values of sediment from the Wilson Creek Formation, Mono Basin, California, indicate three scales of temporal variation (Dansgaard-Oeschger, Heinrich, and Milankovitch) in the hydrologic balance of Mono Lake between 35,400 and 12,900 ${ }^{14} \mathrm{C}$ yr B.P. During this interval, Mono Lake experienced four lowstands each lasting from 1000 to $2000 \mathrm{yr}$. The youngest lowstand, which occurred between 15,500 and $14,000{ }^{14} \mathrm{C}$ yr B.P., was nearly synchronous with a desiccation of Owens Lake, California. Paleomagnetic secular variation (PSV) data indicate that three of four persistent lowstands occurred at the same times as Heinrich events $\mathrm{H} 1, \mathrm{H} 2$, and $\mathrm{H} 4 .{ }^{18} \mathrm{O}$ data indicate the two highest lake levels occurred $\sim 18,000$ and $\sim 13,100{ }^{14} \mathrm{C}$ yr B.P., corresponding to passages of the mean position of the polar jet stream over the Mono Basin. Extremely low values of total inorganic carbon between 26,000 and $14,000{ }^{14} \mathrm{C}$ yr B.P. indicate glacial activity, corresponding to a time when summer insolation was much reduced. (1998 University of Washington.
\end{abstract}

\section{INTRODUCTION}

During the last glacial age, ice-core and marine records indicate that the climate of the North Atlantic region was characterized by alternating cool-warm intervals (Dans-
gaard-Oeschger cycles) that lasted between 500 and 2000 yr (Bond et al., 1993; Bond and Lotti, 1995). The strongest of the cool intervals were often terminated by the massive discharge of icebergs (Heinrich events) from ice sheets surrounding the North Atlantic (Bond et al., 1992; Broecker, 1994). Abrupt warming followed the Heinrich events. In recent papers (Benson et al., 1996a, 1997a) it was shown that Owens Basin, California, was relatively dry during the occurrence of the North Atlantic region Younger Dryas (Heinrich event H0), Older Dryas, Oldest Dryas, and Heinrich $\mathrm{H} 1$ and $\mathrm{H} 2$ events.

Chemical records from sediment cores taken in Owens Lake, California, indicate that major advances of Sierran glaciers occurred between 52,500 and $12,500{ }^{14} \mathrm{C}$ yr B.P. (Fig. 1). The glacial advances appear to have been accompanied by decreases in the amount of water entering Owens Lake (Benson et al., 1996a). These data indicate that the Owens Basin was cold and dry when the North Atlantic region was cold. ${ }^{1}$ Unfortunately, ${ }^{14} \mathrm{C}$ age controls for the

\footnotetext{
${ }^{1}$ During glacial advances, the total organic carbon content of Owens Lake decreased, indicating that productivity decreased in response to decreases in air and water temperatures and to decreases in light penetration that accompanied the input of turbid melt water. During some advances, $\delta^{18} \mathrm{O}$
} 


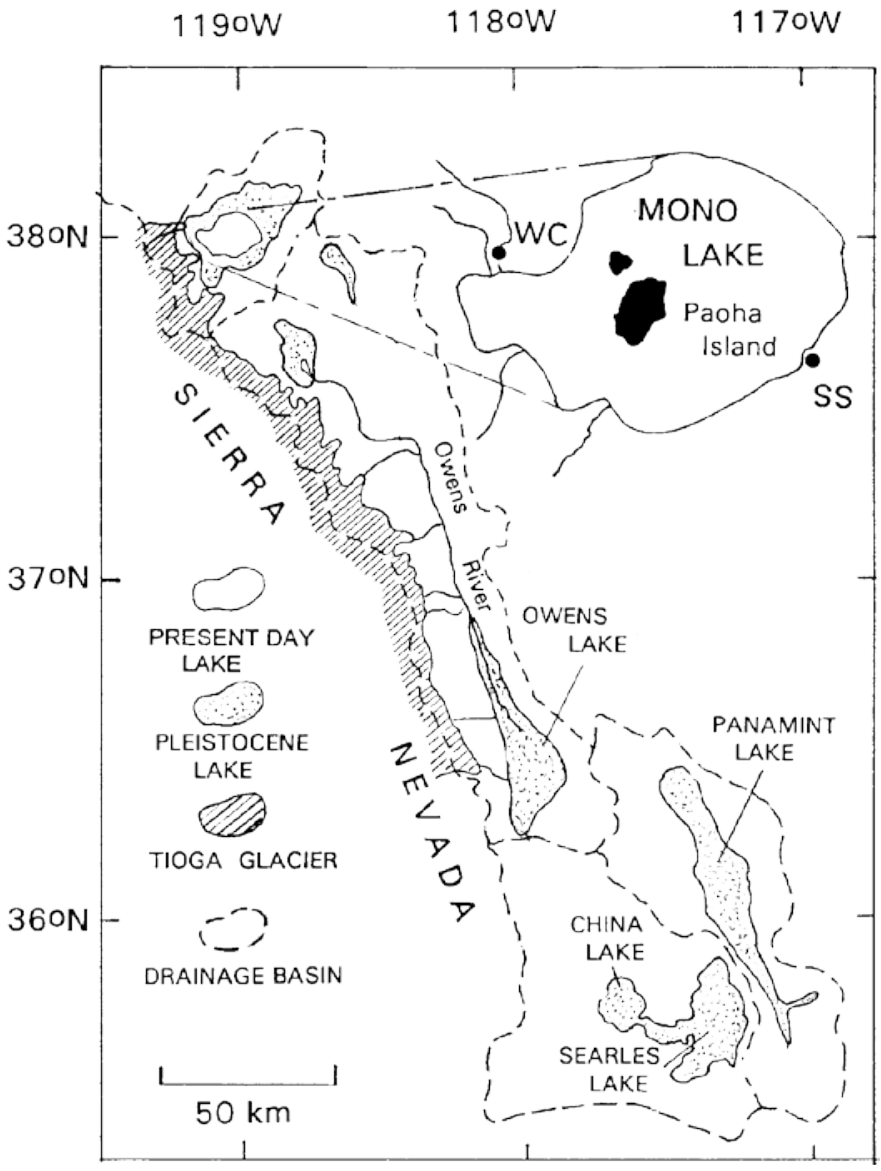

FIG. 1. Map showing location of the Mono and Owens Lake basins WC refers to the location of the Wilson Creek type section and SS refers to the South Shore site from which samples between Ashes 4 and 5 were obtained. The South Shore site is $17 \mathrm{~m}$ lower in elevation than the type section and appears to have remained submerged during shallow-water reworking of sediments at the type section. Generalized area of Tioga valley glaciers and ice caps was modified from Wahrhaftig and Birman (1965).

Owens Lake and North Atlantic records are not sufficiently accurate to allow objective comparison of millennial-scale climatic oscillations prior to $20,000{ }^{14} \mathrm{C}$ yr B.P.

In this study, we have employed paleomagnetic secular variation (PSV) data obtained on North Atlantic and Mono Lake sediments as well as ${ }^{18} \mathrm{O}$ and total inorganic carbon (TIC) measurements of Mono Lake sediments to show that lowstands of Mono Lake occurred during Heinrich events $\mathrm{H} 1, \mathrm{H} 2$, and $\mathrm{H} 4$. These results enforce the concept that relatively dry-wet oscillations in the climate of the Great Basin of the western United States occurred at approximately the same times as cold-warm oscillations in the climate of the North Atlantic region.

values increased, indicating that spill from Owens Lake decreased or even ceased. Note that we use the word "dry" in a relative sense as some of the dry intervals in the late Pleistocene were not as dry as today's climate.

\section{STUDY AREA}

Mono Lake is located in a structural depression at the western edge of the Great Basin, directly north of the Owens Lake Basin (Fig. 1). This closed-basin lake lies in the rain shadow of the Sierra Nevada which receives most of its precipitation in the cool season when the mean position of the polar jet stream lies between 37 and $39^{\circ} \mathrm{N}$ (Starrett, 1949; Pyke, 1972).

The last lake-level maximum (highstand) of Mono Lake ${ }^{2}$ occurred $\sim 13,000{ }^{14} \mathrm{C}$ yr B.P. (Fig. 2). Variations in lake size prior to $15,000{ }^{14} \mathrm{C}$ yr B.P. have proven difficult to document using surficial materials, although (Lajoie et al., 1982) have argued that brief highstands of Mono Lake also occurred at $\sim 34,000$ and $\sim 26,000{ }^{14} \mathrm{C}$ yr B.P. (Benson et al., 1990, Fig. 14).

To obtain a high-resolution record of lake-level change in the Mono Basin, we sampled the late Pleistocene Wilson Creek Formation which crops out along the periphery of Mono Lake. The Wilson Creek Formation, which consists of 6 to $15 \mathrm{~m}$ of finely laminated muds and silts, contains 19 tephra layers (ashes) that provide stratigraphic control throughout the basin (Plates 2 and 3, Lajoie, 1968). The sediments and volcanic tephra layers of the Wilson Creek Formation are described in Lajoie (1968). With the exception of Ash 2, a 3- to 6-m-thick basaltic tephra layer derived from Black Point, the other tephra layers are rhyolitic. In its type section (Fig. 1), the Wilson Creek Formation contains $\sim 7 \mathrm{~m}$ of lacustrine sediments that overlie fluvial gravel, containing small lenses of sand. With the exception of a few sand units located between Ashes 4 and 5, the sediments of the Wilson Creek Formation have the same style, consisting of laminated and structureless muddy silts. Little or no expandable clays have been found in Wilson Creek sediments and the carbonate fraction consists solely of calcite. Ostracodes usually compose $\ll 15 \%$ of the carbonate fraction ( $\mathrm{L}$. Benson and $\mathrm{M}$. Weimer, unpublished data).

In the type section, the Ash 4 to 5 interval is characterized by contorted and deformed bedding (Fig. 3; Lajoie, 1968, Fig. 14A, Plates 2 and 3). A series of imbricate thrusts that repeat parts of the section in this interval are believed to have formed in response to loading by Ash 2. Ash 2 is itself irregularly bedded and contorted in the Wilson and Mill Creek areas (Lajoie, 1968, Photo no. 22). At its South Shore site (Lajoie, 1968, Plate 13; Fig. 1), the Wilson Creek Formation is thicker than the type section and $17 \mathrm{~m}$ lower in elevation. At this site, the sediments between Ash 4 and 5 are neither contorted nor deformed. Comparison of paleomagnetic-field directions (inclination and declination) obtained from the Wilson Creek Formation at its type and

\footnotetext{
${ }^{2}$ Although the lake that occupied the Mono Basin in the late Pleistocene has often been referred to as Lake Russell in honor of I. C. Russell (Russell, 1889), in this paper, we will refer to the lake that has intermittently occupied the Mono Basin during the Quaternary by its modern name-Mono Lake.
} 


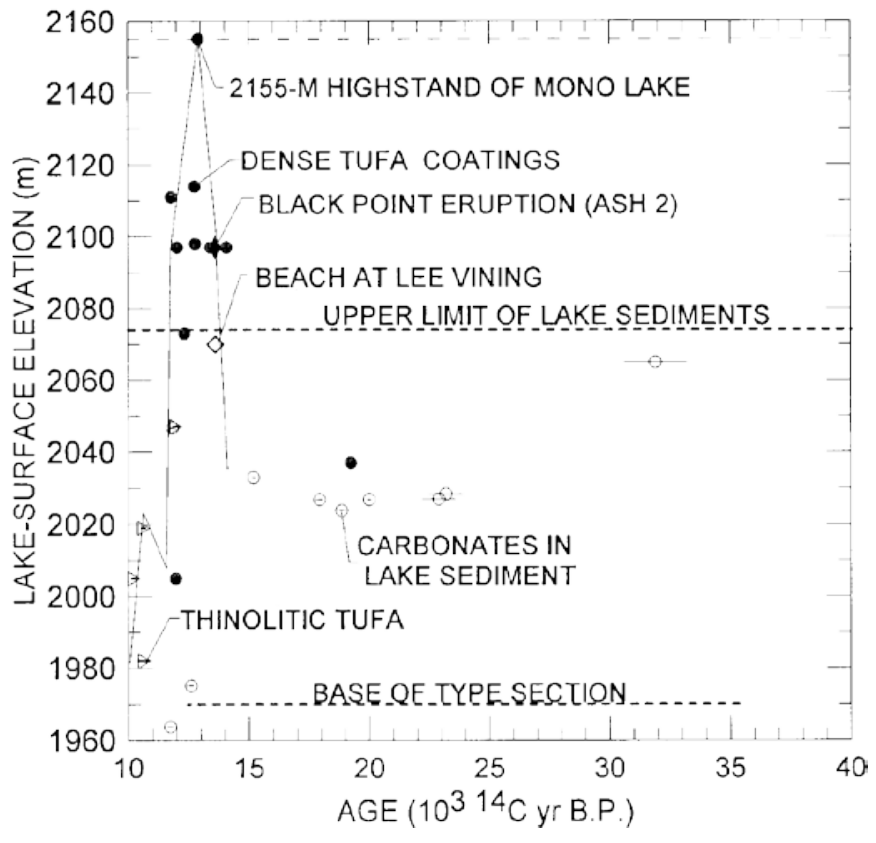

FIG. 2. Elevation-age plot of selected carbonates (tufas) from the Mono Lake basin. Solid circles indicate relatively dense tufas; open circles indicate carbonates found in lake sediments above the elevation of the Wilson Creek type section. Lake-surface elevation at time of Black Point eruption $\left(13,610{ }^{14} \mathrm{C}\right.$ yr B.P., Table 1$)$ was determined from a bathtub ring of basaltic pumice (Ash 2) deposited in Mono Lake basin. The carbonate data indicate that Mono Lake (Pleistocene Lake Russell) achieved a highstand at $\sim 13,000{ }^{14} \mathrm{C}$ yr B.P. Thinolitic tufa often yields unreliable ${ }^{14} \mathrm{C}$ ages; i.e., it is thought to have formed as the metastable hexahydrate of $\mathrm{CaCO}_{3}$. It is plotted here because it may have recrystallized soon after subaerial exposure and therefore may date a decline of Mono Lake.

South Shore sites indicates that sediment is missing between Ashes 4 and 5 at the type section (J. C. Liddicoat and S. P. Lund, unpublished data).

\section{METHODS}

To rectify the problem of missing and repeated intervals of sedimentation between Ashes 4 and 5, we obtained a nearly continuous set of 2-cm-thick samples from the South Shore site (Fig. 1). Samples also were taken several $\mathrm{cm}$ above and below Ashes 4 and 5 at the South Shore site to ensure data overlap with the Wilson Creek isotope site. At the South Shore site, the Ash 4-5 interval (3.66 m) is much thicker than the same interval at the type locality, implying that the South Shore site may have escaped erosion during the time interval that separated ash deposition.

At the Wilson Creek isotope site, a continuous set of 2$\mathrm{cm}$-thick samples each weighing $\sim 200 \mathrm{~g}$ and integrating $\leq 70 \mathrm{yr}$ were analyzed for $\delta^{18} \mathrm{O}$. Samples from both sites were washed in deionized water, freeze dried, and homogenized prior to analysis. ${ }^{18} \mathrm{O}$ values obtained on the total inorganic fraction (low-magnesium calcite) are reported relative to the VSMOW standard. Analytical procedures are discussed in Benson et al. (1996a).

\section{AGE CONTROL}

Radiocarbon ages of carbonate samples from the Wilson Creek Formation, as well as the distances of the samples above and below tephra layers (Benson et al., 1990, Table IV), were used to construct an age model for the Wilson Creek type section. Linear regression of data between Ashes 1 and 4 and between Ashes 5 and 19 (Fig. 4a) was used to estimate the ${ }^{14} \mathrm{C}$ ages of individual tephra layers (Table 1). Age estimates for the tephra layers (Table 1), together with two new AMS ${ }^{14} \mathrm{C}$ determinations on unaltered ostracode valves, were then used to set the chronology for samples obtained in this study from our main isotope sampling site (Fig. 4b). Given the fit of our linear age-depth models, we consider its accuracy to be no better than a thousand years.

Our main 6.94-m-thick isotope sampling site was located near exposures originally used to construct the 7.17-m type section and contains a sequence of sediments deposited between 35,400 and $12,900 \mathrm{yr}$ B.P. A linear fit using the ages of and depth interval between Ashes 4 and 5 was used to estimate the ages of samples taken from the South Shore site.

\section{RESULTS AND DISCUSSION}

\section{Correlations of Lake-Size Changes with Climate Change in the North Atlantic Region}

In a hydrologically closed lake, increases in lake volume resulting from input of isotopically light streamflow discharge and on-lake precipitation are reflected in decreased values of $\delta^{18} \mathrm{O}$. The greater the change in volume the more abrupt the change in $\delta^{18} \mathrm{O}$ (Benson et al., 1996b; Gat, 1981). ${ }^{18} \mathrm{O}$ data from the Wilson Creek Formation (Fig. 5) indicate the existence of three scales of temporal variation in the hydrologic balance.

The $10^{3}$-year scale in hydrologic variability is evidenced by 500 - to $1500-\mathrm{yr}$ oscillations in the size ( $\delta^{18} \mathrm{O}$ value) of Mono Lake. The oscillations are most clearly displayed in the plot that represents the running mean of three successive measurements of $\delta^{18} \mathrm{O}$ (Fig. 5). This scale of hydrologic variance is similar to the scale but not amplitude of variance in air temperature recorded in Greenland ice core GISP2. The $\delta^{18} \mathrm{O}$ data from the GISP2 core (Grootes et al., 1993; Stuiver et al., 1995) depicted in Figure 5 was converted from its "absolute" chronology (Meese et al., 1994) to a ${ }^{14} \mathrm{C}$ chronology using the data of (Bard et al., 1993). The ${ }^{14} \mathrm{C}$ chronology was then "stretched" to place the Heinrich events that matched to Dansgaard-Oeschger cycles at $14,000,21,000,27,000$, and 35,500 yr B.P.

The multimillennial (Heinrich) scale in hydrologic variance is evidenced by persistent lowstands (L1 through L4) of Mono Lake (high values of $\delta^{18} \mathrm{O}$ ) that occurred every 
BENSON ET AL.

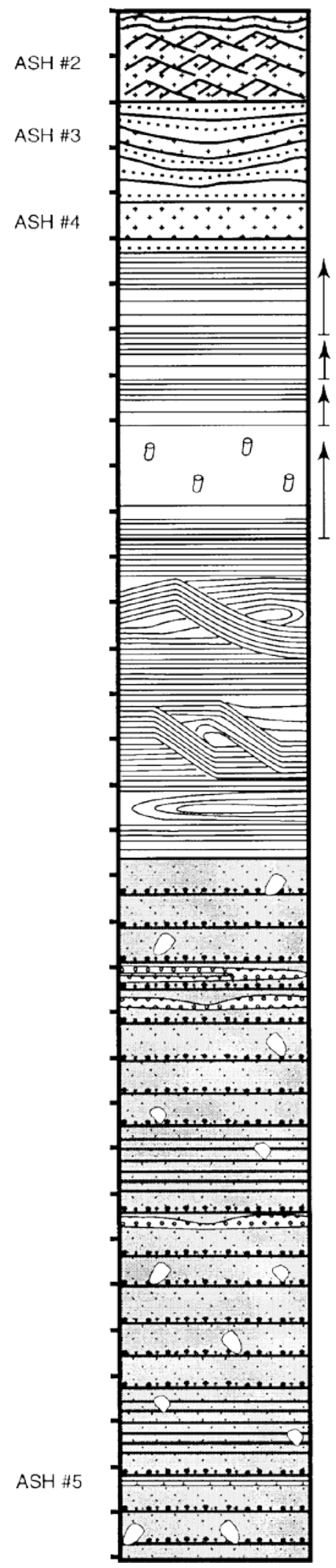

Dark green tuffaceous sand with climbing-ripple cross lamination

Ostracode-rich sand and silty mud forming

graded thick laminae and pinch-and swell layers.

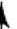

Three intervals of thick laminae of ostracode-rich

silty mud grading into thin laminae of calcareous clay.

Thinly laminated calcareous clay becoming thicker bedded upwards and more silty with ostracodes and burrows

Clay with thin laminae of diatoms(?). Imbricate thrusts and folds are common. Layers are thicker and more silt rich toward base.

Silty mud thin beds with sharp sandy bases. Oversized pebbles and cobbles (drop stones) are common. Sandy layers have irregular thicknesses and in one case comprises an overturned fold.

Silty mud with thick laminae defined by carbonate content Oversized pebbles and cobbles (drop stones) are common.

Silty mud thin beds with sharp sandy bases. Oversized pebbles and cobbles (drop stones) are common. Sandy layers have irregular thicknesses.

Silty mud with thick laminae defined by carbonate content Oversized pebbles and cobbles (drop stones) are common.

Silty mud thin beds with sharp sandy bases. Oversized pebbles and cobbles (drop stones) are common.

FIG. 3. Partial stratigraphic section of sediments exposed along Wilson Creek at the type locality of the Wilson Creek Formation. Ash unit numbers from Lajoie (1968). Tick marks define 10-cm intervals. The clay unit with imbricate thrusts is probably a glide plane for a slump caused by deposition of Ash 2. 

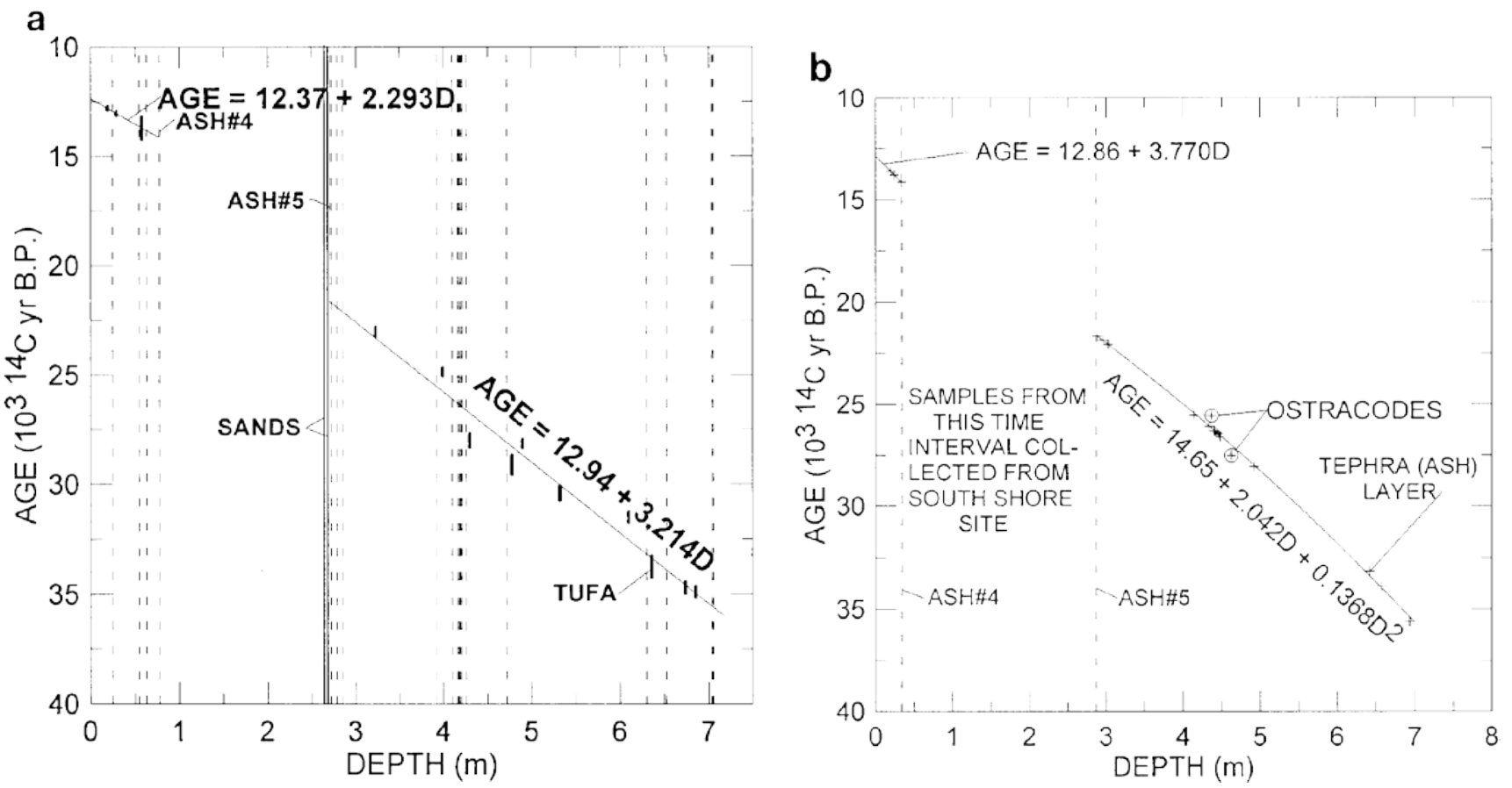

FIG. 4. (a) Radiocarbon ages and depths of carbonates in the Wilson Creek area used to estimate the ages of 19 tephra layers (ashes) exposed in the Wilson Creek Formation along Wilson Creek. Ashes are depicted as vertical dashed lines. Data used in this figure were taken from Wilson Creek type section listing in Table IV in Benson et al. (1990). In the regression equations, $D$ refers to depth in meters (m). In constructing the two regression lines, some samples from Table IV were rejected. Sample USGS-1435 came from the reworked Ash 4-5 interval. Radiocarbon ages of samples USGS1436 and L-1167C were splits from the same collection of ostracode valves whose radiocarbon ages are anomalously young $(\sim 23,000$ instead of $\sim 26,000$ ${ }^{14} \mathrm{C}$ yr). We expect that modern carbon was added to many of the thin-walled ostracode valves. The radiocarbon age of sample USGS-362, a nodular tufa with carbonate coatings from the base of the Wilson Creek Formation, was also clearly too young $\left(28,600 \mathrm{instead} \mathrm{of} \sim 36,000{ }^{14} \mathrm{C}\right.$ yr). Sample USGS-276 was rejected because its ${ }^{14} \mathrm{C}$ age was infinite $\left(39,600{ }^{14} \mathrm{C}\right.$ yr). (b) Radiocarbon age control for Wilson Creek isotope section. Age control is based on estimated ages of 18 tephra layers (Table 1). The two ostracode AMS ${ }^{14} \mathrm{C}$ ages provide a check on the reliability of the tephra-derived age model for the interval 25,000 to $27,500{ }^{14} \mathrm{C}$ yr B.P.

6000 to 7000 years. Given the ${ }^{14} \mathrm{C}$-based chronologies for the marine and lacustrine data sets, it appears that the youngest prominent lowstands of Mono Lake occurred during Heinrich events H1 through $\mathrm{H} 3$ (Fig. 5).

Radiocarbon reservoir effects, however, are neither constant nor easily quantified in marine and lacustrine environments; e.g., modern tufas in Mono Lake have ${ }^{14} \mathrm{C}$ ages ranging from 1100 to $2100{ }^{14} \mathrm{C}$ years (Benson et al., 1990). Because much of the reservoir effect in Mono Lake may have resulted from inputs of ${ }^{14} \mathrm{C}$-free carbon accompanying subsurface volcanism, the pre-Holocene value of the reservoir effect may have at times been of the same magnitude as the modern effect, given the history of volcanism evidenced by the 19 tephra layers contained within Wilson Creek sediments.

Porous lacustrine carbonates typical of the Mono Basin, however, do not remain closed systems with respect to carbon. Such carbonates tend to acquire ${ }^{14} \mathrm{C}$ when exposed to the subaerial environment by a dissolution-reprecipitation process that occurs when low-pH rain comes in contact with the carbonate. This process can decrease the apparent ${ }^{14} \mathrm{C}$ age of porous carbonates by more than 1000 years (Thompson et al., 1986). Because carbonates can acquire modern carbon during their entire tenure in the subaerial environment, the apparent ${ }^{14} \mathrm{C}$ ages of the oldest Mono Lake tufas may be much younger than the events they appear to date. For these reasons, we turned to another method of comparison to test the hypothesis that Mono Lake lowstands accompanied periods of intense ice rafting in the North Atlantic Ocean.

Recently Lund (1996) has shown that distinctive magnetic-field features in Holocene records of paleomagnetic secular variation (PSV) can be traced across North America for more than $4000 \mathrm{~km}$ without change in pattern. In this paper, we have applied this concept, which assumes nearly synchronous (within \pm 100 to 200 years) field variability, to PSV records from Mono Lake and the North Atlantic Ocean. The likelihood that lowstands of Mono Lake were synchronous with Heinrich events was tested using data from two deep-sea sediment cores from the western North Atlantic (P094 located at $50.2^{\circ} \mathrm{N}, 45.7^{\circ} \mathrm{W}$ and CH88-10P located at $29.6^{\circ} \mathrm{N}, 73.3^{\circ} \mathrm{W}$; Haskell et al., 1991; Stoner et al., 1995; Stoner et al., 1996). Four detrital carbonate intervals (DC1 through DC4) identified in P-094 are considered equivalent to Heinrich events H1 through H4 (Stoner et al., 1995; Stoner et al., 1996). The carbonate and oxygen-isotope stra- 
TABLE 1

Radiocarbon Ages for the Wilson Creek Formation

\begin{tabular}{|c|c|c|c|}
\hline Ostracode sample & CAMS no. $^{a}$ & Depth in isotope section (m) & $\begin{array}{l}\text { Radiocarbon age (uncalibrated) } \\
{ }^{14} \text { C yr B.P. } \pm 1 \text { std. dev. }\end{array}$ \\
\hline OST:436-438 & 20031 & 4.37 & $25,570 \pm 260$ \\
\hline Tephra layer & Depth in isotope section $(\mathrm{m})$ & Estimated age ${ }^{14} \mathrm{C}$ yr B.P. ${ }^{b}$ & Depth in type section (m) \\
\hline Ash \#3 & 0.24 & 13,790 & 0.62 \\
\hline Ash \#4 & 0.34 & 14,140 & 0.77 \\
\hline Ash \#5 & 2.88 & 21,680 & 2.72 \\
\hline Ash \#6 & 2.96 & 21,870 & 2.78 \\
\hline Ash \#7 & 3.02 & 22,070 & 2.84 \\
\hline Ash \#8 & 4.14 & 25,540 & 3.92 \\
\hline Ash \#14 & 4.48 & 26,600 & 4.25 \\
\hline Ash \#15 & 4.92 & 28,080 & 4.71 \\
\hline Ash \#16 & 6.42 & 33,160 & 6.29 \\
\hline Ash \#17 & 6.57 & 33,900 & 6.52 \\
\hline Ash \#18 & - & 35,530 & 7.03 \\
\hline Ash \#19 & 6.94 & 35,600 & 7.05 \\
\hline
\end{tabular}

${ }^{a}$ CAMS, Samples analyzed by Center for Accelerator Mass Spectrometry (CAMS) facility at Lawrence Livermore National Laboratory.

${ }^{b}$ Radiocarbon ages estimated by interpolation using the age model of Figure 4a. Ages of Ashes \#1-\#14 are probably accurate within 500 yr. After $27,000{ }^{14} \mathrm{C}$ yr B.P., paleomagnetic secular variation data for the Wilson Creek type section and deep-sea core records (see text for discussion) indicate that Wilson Creek tufa based ${ }^{14} \mathrm{C}$ age estimates of Ashes \#15-\#19 are too young. The marine-based ${ }^{14} \mathrm{C}$ age model indicates the following ${ }^{14} \mathrm{C}$ ages for Ashes \#15-\#19: 31,500, 37,000, 38,000, >40,000, and $>40,000{ }^{14} \mathrm{C}$ yr B.P.

tigraphies of $\mathrm{CH} 88-10 \mathrm{P}$ were then used to estimate the locations of Heinrich events $\mathrm{H} 1$ through $\mathrm{H} 4$ in this core, using previously developed correlations between these stratigraphies and Heinrich events (Bond et al., 1993; Keigwin and Jones, 1994; Bond and Lotti, 1995).

Paleomagnetic field directional and intensity variations recorded in CH88-10P sediments (Lund, 1993; Schwartz et al., 1996a) and P-094 (Stoner et al., 1995; Stoner et al., 1996) were used to create a magnetic chronostratigraphy in which each Heinrich event was associated with directional features of the magnetic records. We then correlated intensity records for P-094 and CH88-10P (Lund et al., 1988; Schwartz et al., 1996b) and directional records (both inclination and declination) for CH88-10P with Wilson Creek PSV features to determine what Mono Lake $\delta^{18} \mathrm{O}$ features were associated with Heinrich events (Fig. 6).

From the PSV data, it is apparent that Heinrich events H1, $\mathrm{H} 2$, and $\mathrm{H} 4$ and Mono Lake lowstands L1, L2, and L4 are nearly synchronous; however, $\mathrm{H} 3$ does not correlate with any Mono Lake lowstand. Lowstand L1 is of particular interest because it occurred at very nearly the same time $(15,500$ to $14,000{ }^{14} \mathrm{C}$ yr B.P.) as a drying of Owens Lake $(15,500$ to $\sim 13,300{ }^{14} \mathrm{C}$ yr B.P.). A sediment core taken from Pyramid Lake in the Lahontan Basin also indicates a maximum in $\delta^{18} \mathrm{O}$ values at $14,500{ }^{14} \mathrm{C}$ yr B.P. (L. V. Benson, unpublished data).

Negrini (1997) has associated the Wono tephra layer dated at $27,300 \pm 300{ }^{14} \mathrm{C}$ yr B.P. (Benson et al., 1997b) with paleomagnetic inclination features of Lake Chewaucan sediments that can be correlated with inclination features in the Wilson Creek Formation (Fig. 6). The correlation indicates that our Wilson Creek age model is correct back to 27,000 ${ }^{14} \mathrm{C}$ yr B.P. If our PSV approach is correct, it implies that lake and marine ${ }^{14} \mathrm{C}$ time scales began to diverge at $\geq 27,000$ ${ }^{14} \mathrm{C}$ yr B.P. and that by $35,000{ }^{14} \mathrm{C}$ yr B.P. (Mono Lake time scale) ${ }^{14} \mathrm{C}$ ages of Mono Lake carbonates are $\sim 3000 \mathrm{yr}$ too young relative to the marine time scale. This suggests that either the marine reservoir effect has been underestimated or, more likely, that the addition of $0.3 \%$ modern carbon has shifted the ages of the oldest Mono Lake tufas. This also implies that the ages of Wilson Creek Ashes 15-19 (Table 1) have been underestimated with our age model.

The fact that $\mathrm{H} 3$ is not associated with any persistent lowstand of Mono Lake is of particular interest because H3 is considered to mostly have originated from sources other 


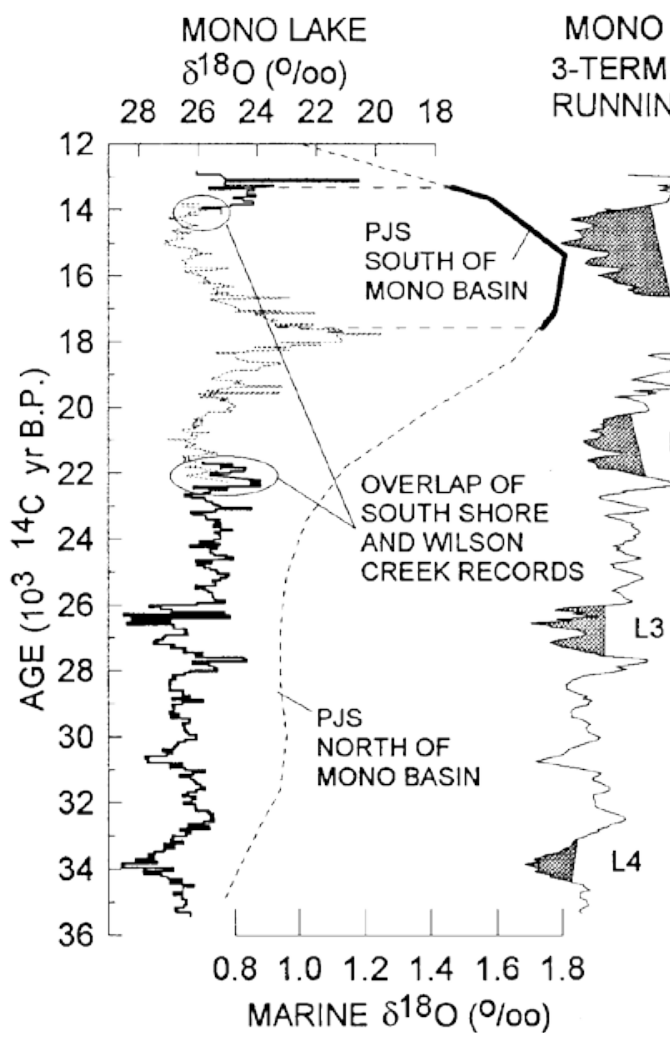

MONO LAKE

3-TERM $\delta 18 \mathrm{O}$

RUNNING AVG

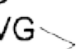

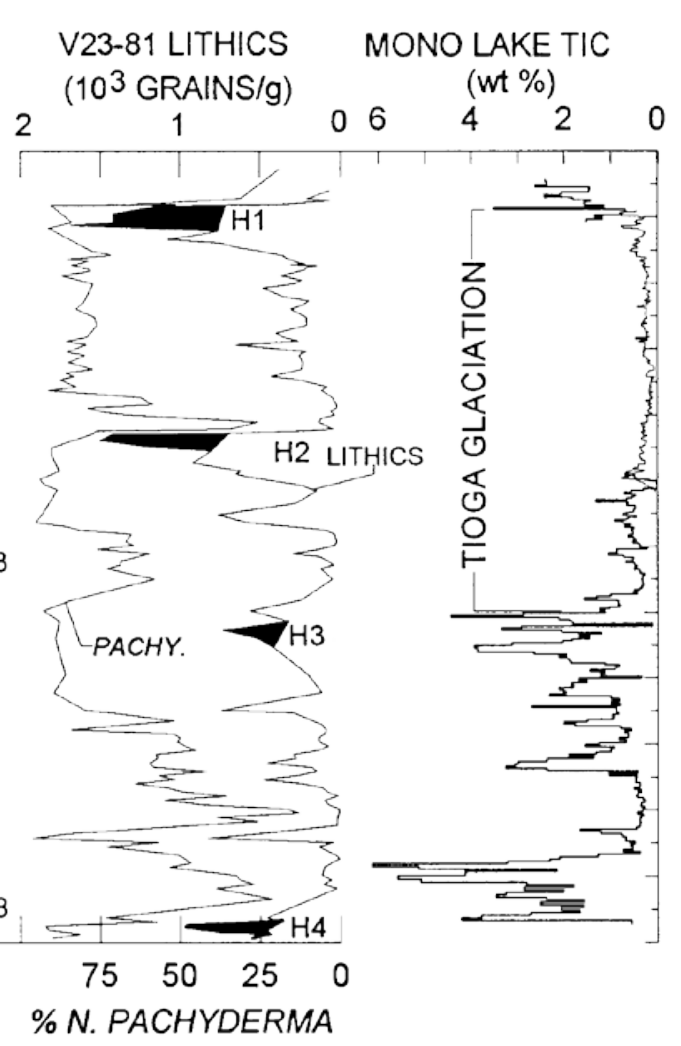

FIG. 5. $\quad \delta^{18} \mathrm{O}$ and TIC records from Wilson Creek sediments compared with the lithic and Neogloboquadrina pachyderma (left-coiling) records from North Atlantic core V23-81, the SPECMAP stacked marine $\delta^{18} \mathrm{O}$ record (Imbrie et al., 1984), and the $\delta^{18} \mathrm{O}$ record from GISP2 ice core, Greenland (Grootes et al., 1993; Stuiver et al., 1995). H1 to H4 refer to North Atlantic Heinrich (Heinrich, 1988) events; L1 to L4 refer to principal lowstands of Mono Lake, D2 to D8 refers to Dansgaard-Oeschger interstades. Placement of Heinrich events on the GISP2 record follows Bond and Lotti (1995).

than the Laurentide ice sheet (Grousset et al., 1993; Gwiazda et al., 1996). This implies that only massive ice rafting events, originating in the Laurentide ice sheet, were capable of perturbing the climate of the Mono Lake area, possibly through the effect of the ice sheet on the trajectory of the polar jet stream. This also lends support to the hypothesis of MacAyeal (1993) that surging of the Hudson Bay lobe of the Laurentide ice sheet caused Heinrich events.

Clark and Bartlein (1995) have recently suggested that late Pleistocene alpine glaciers in the western United States advanced to their terminal areas up to several thousand years before a Heinrich event and retreated shortly thereafter. The data presented in Clark and Bartlein (1995), though of low resolution, are consistent with the data presented herein which indicate that $\mathrm{H} 1, \mathrm{H} 2$, and $\mathrm{H} 4$ occurred during cold and relatively dry periods.

The $10^{4}$-yr (Milankovitch) scale of climate variability is evidenced by parallelism between the overall trend in the Wilson Creek and marine $\delta^{18} \mathrm{O}$ records from 35,500 to $18,000{ }^{14} \mathrm{C}$ yr B.P. (Fig. 5). ${ }^{3}$ This parallelism is inter-

\footnotetext{
${ }^{3}$ The stacked marine $\delta^{18} \mathrm{O}$ record (PDB standard) is assumed to be a proxy for the size of the Laurentide Ice Sheet during the last glacial (Imbrie et al., 1984).
}

preted to indicate the gradual southward movement of the mean position of the polar jet stream in response to increasing size of the Laurentide ice sheet (Antevs, 1948; Benson and Thompson, 1987; Kutzbach and Guetter, 1986). The lack of parallelism between 18,000 and 13,000 ${ }^{14} \mathrm{C}$ yr B.P. is interpreted to indicate that the polar jet stream was forced south of the Mono Basin $\left(38^{\circ} \mathrm{N}\right)$ as the ice sheet expanded. The two lake-level maxima $\left(\delta^{18} \mathrm{O}\right.$ minima), centered at 18,000 and $13,100{ }^{14} \mathrm{C}$ yr B.P., therefore, correspond to two passages of the polar jet stream core over the Mono Basin. ${ }^{4}$

The $13,100{ }^{14} \mathrm{C}$ yr B.P. sediment-based highstand occurs at essentially the same time as the tufa-based highstand, previously dated at $13,000{ }^{14} \mathrm{C}$ yr B.P. (Fig. 2). The highstand at $18,000{ }^{14} \mathrm{C}$ yr B.P. was not recorded in the tufa-based lake-level record (Fig. 2). This probably reflects the erodable nature of the substrate (silts and sands) on which carbonates were deposited; i.e., the transgression to the $13,100{ }^{14} \mathrm{C}$ yr B.P. highstand effectively removed most of the older surficial carbonates deposited during previous highstands.

\footnotetext{
${ }^{4}$ Benson et al. (1995) previously suggested this mechanism for the large and abrupt increases in the level of Lake Lahontan that occurred at $\sim 21,000$ and $\sim 14,500{ }^{14} \mathrm{C}$ yr B.P.
} 
Glaciation of the Mono Basin

In the Owens Basin, the Tioga glaciation occurred between $\sim 25,000$ and $\sim 15,000{ }^{14} \mathrm{C}$ yr B.P. as indicated by

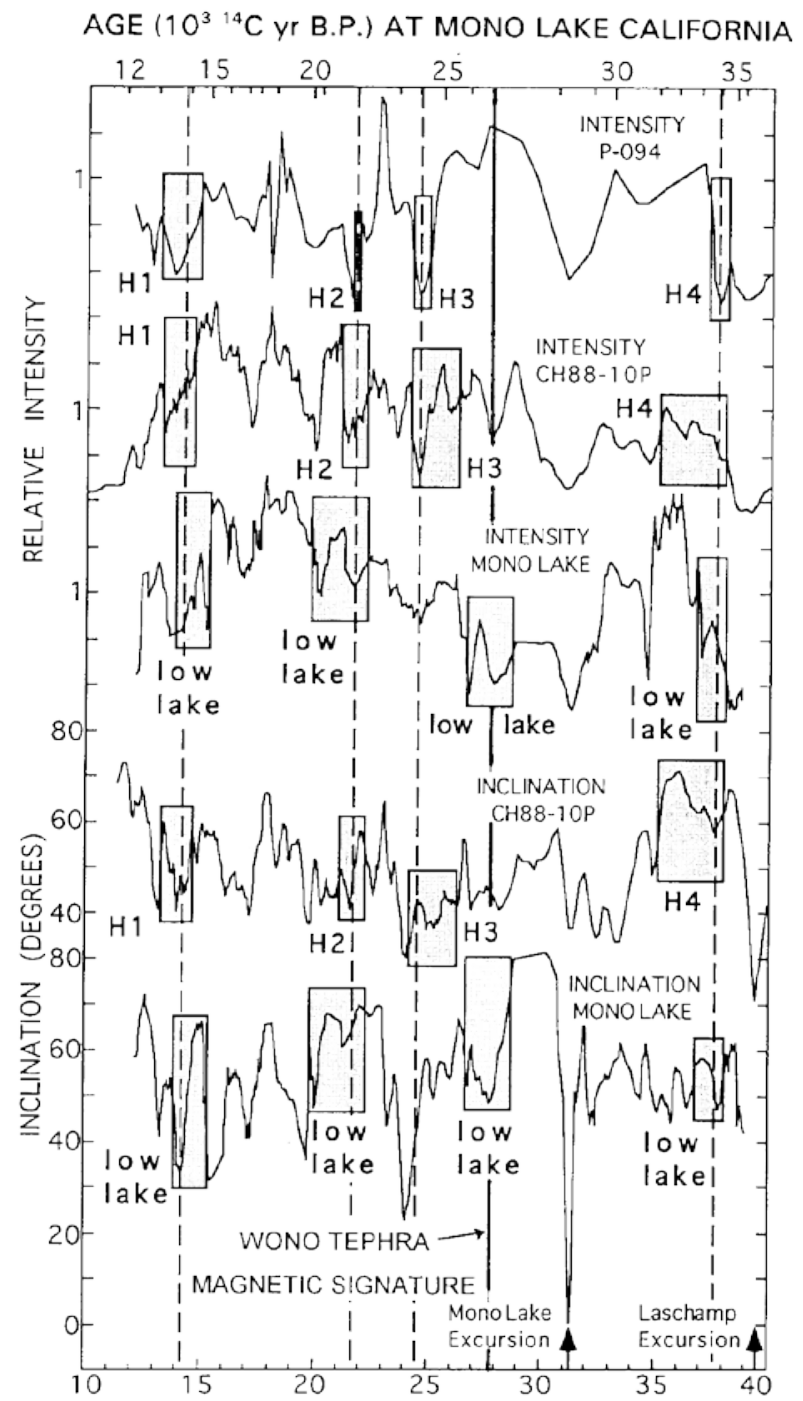

AGE $\left(10^{3}{ }^{14} \mathrm{C}\right.$ yr B.P. $)$ IN N. ATLANTIC CORE CH88-1OP

FIG. 6. Comparison of Heinrich event and Mono Lake lowstand ages using paleomagnetic field variability (intensity and inclination) for chronostratigraphic control. Methodology for placement of the Heinrich events on the paleomagnetic waveforms is discussed in the text. The stratigraphic locations of Heinrich events in North Atlantic cores CH88-10P, and P-094 are indicated by gray boxes labeled $\mathrm{H} 1$ through $\mathrm{H} 4$. Mono Lake lowstands are shown as gray boxes labeled "low lake." The paleomagnetic data indicate that Heinrich events H1, $\mathrm{H} 2$, and $\mathrm{H} 4$ occurred during Mono low-lake intervals, whereas, Heinrich event H3 did not. Note that the intensity record of Mono Lake is sufficient to show the correlation between L4 and H4 but the inclination record is equivocal. The ${ }^{14} \mathrm{C}$ chronology for CH88-10P (Keigwin and Jones, 1989; Keigwin and Jones, 1994) was used to develop a common time scale for the marine records (Fig 6). Radiocarbon ages of Mono Lake sediments are shown in the upper abscissa and radiocarbon ages of marine sediments are shown in the lower abscissa. The location of the inclination feature associated with the $27,300{ }^{14} \mathrm{C}$ yr old Wono tephra layer is indicated by a solid vertical line.

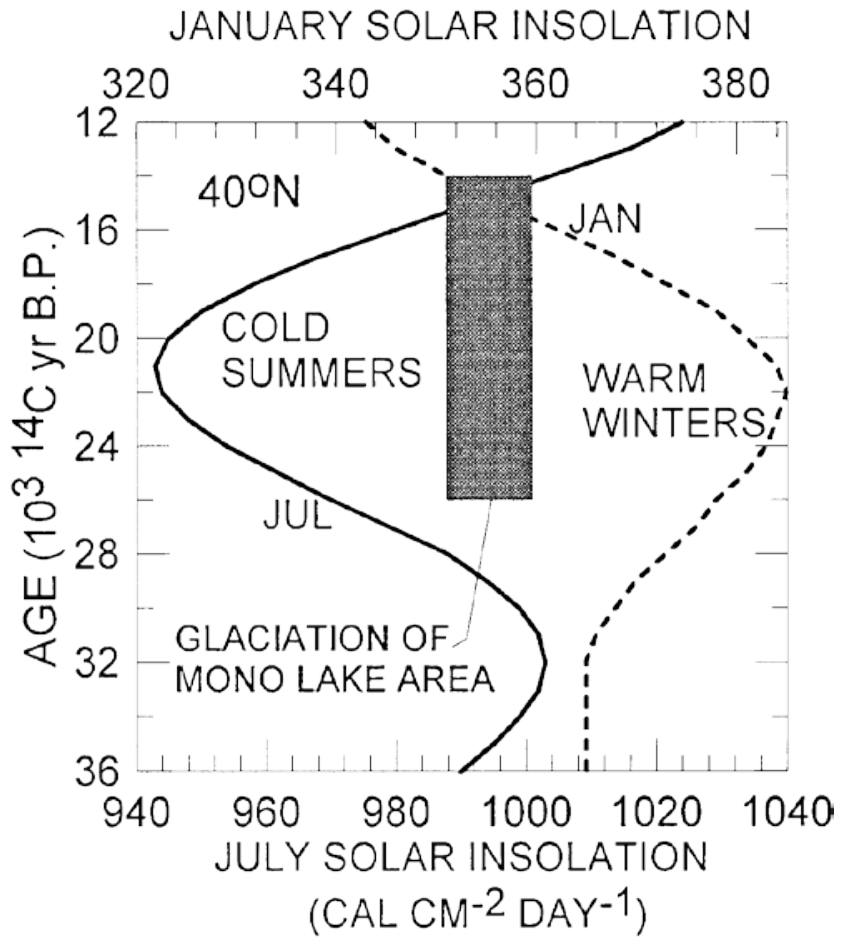

FIG. 7. Values of January and July insolation at $40^{\circ} \mathrm{N}$ for the period 36,000 to $12,000{ }^{14} \mathrm{C}$ yr B.P. The period of intense glaciation recorded by the TIC fraction of Mono Lake sediments occurred during a time characterized by cold summers and warm winters.

increased magnetic susceptibility and decreased TIC and total organic carbon (TOC) concentrations in cored sediments (Benson et al., 1996a).

In a closed basin lake, such as Mono Lake, changes in TIC are expected to parallel changes in $\delta^{18} \mathrm{O}$ unless the influx of detrital silicates masks the TIC signal (Benson et al., 1996a). Though the amplitude of the variations differ in the two data sets, such a parallelism does occur in the Mono Lake record between 35,400 and $26,000{ }^{14} \mathrm{C}$ yr B.P. (Fig. 5). Between 26,000 and $14,000{ }^{14} \mathrm{C}$ yr B.P., however, TIC values are markedly reduced and the TIC and $\delta^{18} \mathrm{O}$ records are unrelated. We attribute the reduction and loss of variability in TIC between 26,000 and $14,000{ }^{14} \mathrm{C}$ yr B.P. to the influx of detrital rock flour that accompanied Tioga glaciation of the Mono Basin (Fig. 5). The Tioga glaciation may have, in part, been the result of reduced summer insolation; e.g., a plot of July insolation at $40^{\circ} \mathrm{N}$ (Fig. 7) indicates extremely low values during the period of interest.

\section{CONCLUSIONS}

Most of the major dry (and probably cool) ${ }^{5}$ periods in the Mono Basin between 35,900 and 12,900 ${ }^{14} \mathrm{C}$ yr B.P. appear

${ }^{5}$ The 2 to $3 \%$ increase in $\delta^{18} \mathrm{O}$ that occurred during the transition to Mono Lake lowstands can also partly be attributed to decreases in water temperature; i.e., fractionation of ${ }^{18} \mathrm{O}$ into calcium carbonate increases by $\sim 0.25 \%$ per ${ }^{\circ} \mathrm{C}$ reduction in water temperature (O’Neil et al., 1969). 
to have occurred at nearly the same time as cool periods in the North Atlantic. Cold-warm oscillations in the North Atlantic region have previously been attributed to abrupt changes in the rate and location of thermohaline overturn (Broecker et al., 1990; Broecker and Denton, 1989; Lehman and Keigwin, 1992; Rind et al., 1986). To the extent that the dry-wet transitions in the Mono Basin are synchronous with cold-warm transitions in the North Atlantic region, our data support the hypothesis that cooling of the North Atlantic caused a downstream cooling of the atmosphere and the North Pacific. This in turn led to a decrease in the amount of moisture reaching the western United States of America.

Age controls for both lacustrine and marine records, however, remain inadequate to demonstrate the absolute synchroneity of climate change across the Northern Hemisphere and it is possible that there are substantial offsets in the timing of climate transitions in both regions. In any case, we envision the polar jet stream as a principal component of the atmospheric teleconnection that linked climate change across the upper part of the Northern Hemisphere (Clark and Bartlein, 1995). Similar high-resolution data from lower latitudes (e.g., $20^{\circ} \mathrm{N}$ ) would help answer the question whether climate change was synchronous and unidirectional across the entire Northern Hemisphere.

\section{ACKNOWLEDGMENTS}

Radiocarbon analyses were performed in part under the auspices of the U.S. Department of Energy by Lawrence Livermore National Laboratory under Contract W-7405-ENG-48. The stable isotope and inorganic carbon analyses were funded by the Global Change Program of the U.S. Geological Survey. Paleomagnetic research was funded by a University of Southern California Faculty Research Innovation Fund grant. We thank Emi Ito and Jack Oviatt for their helpful reviews of earlier versions of this manuscript and Ken Lajoie for his assistance during sampling of the Wilson Creek Formation.

\section{REFERENCES}

Antevs, E. (1948). The Great Basin, with emphasis on glacial and postglacial times - Climatic changes and pre-white man. Bulletin University of Utah Biology Series 38, 168-191.

Bard, E., Arnold, M., Fairbanks, R. G., and Hamelin, B. (1993). ${ }^{230} \mathrm{Th}^{-234} \mathrm{U}$ and ${ }^{14} \mathrm{C}$ ages obtained by mass spectrometry on corals. Radiocarbon 35 , 191-199.

Benson, L. V., Burdett, J. W., Lund, S. P., Kashgarian, M., and Mensing, S. (1997a). Nearly synchronous Northern Hemispheric climate change during the Last Glacial Termination? Nature 388, 263-265.

Benson, L. V., Smoot, J. P., Kashgarian, M., Sarna-Wojcicki, and Burdett, J. W. (1997b). Radiocarbon ages and environments of deposition of the Wono and Trego Hot Spring tephra layers in the Pyramid Lake subbasin, Nevada. Quaternary Research 47, 251-260.

Benson, L. V., Burdett, J. W., Kashgarian, M., Lund, S. P., Phillips, F. M., and Rye, O. R. (1996a). Climatic and Hydrologic oscillations in the Owens Lake Basin and adjacent Sierra Nevada, California. Science 274, 746-749.

Benson, L. V., Currey, D. R., Dorn, R. I., Lajoie, K. R., Oviatt, C. G., Robinson, S. W., Smith, G. I., and Scott, S. (1990). Chronology of expansion and contraction of four Great Basin lake systems during the past 35,000 years. Palaeogeography, Palaeoclimatology, Palaeoecology 78, 241286.

Benson, L. V., and Thompson, R. S. (1987). Lake-level variation in the Lahontan Basin for the past 50,000 years. Quaternary Research 28, 69 85 .

Benson, L. V., Kashgarian, M., and Rubin, M. (1995). Carbonate deposition, Pyramid Lake Subbasin, Nevada: 2. Lake levels and polar jet stream positions reconstructed from radiocarbon ages and elevations of carbonates (tufas) deposited in the Lahontan basin. Palaeogeography, Palaeoclimatology, Palaeoecology 117, 1-30.

Benson, L. V., White, D. W., and Rye, R. (1996b). Carbonate deposition, Pyramid Lake Subbasin, Nevada: 4. Comparison of the stable isotope values of carbonate deposits (tufas) and the Lahontan lake-level record. Palaeogeography, Palaeoclimatology, Palaeoecology 122, 45-76.

Bond, G. C., Broecker, W., Johnsen, S., McManus, J., Labeyrie, L., Jouzel, J., and Bonani, G. (1993). Correlations between climate records from north Atlantic sediments and Greenland ice. Nature 365, 143-147.

Bond, G. C., Heinrich, H., Broecker, W., Labeyrie, L., M., Andrews, J., Huon, S., Jantschik, R., Clasen, S., Simet, C., Tedesco, K., Klas, M., Bononi, G., and Ivy, S. (1992). Evidence for massive discharges of icebergs into the north Atlantic ocean during the last glacial period. Nature 360, 245-249.

Bond, G. C., and Lotti, R. (1995). Iceberg discharges into the north Atlantic on millennial time scales during the last glaciation. Science 267, $1005-$ 1010.

Broecker, W. S. (1994). Massive iceberg discharges as triggers for global climate change. Nature 372, 421-424.

Broecker, W. S., Bond, G., Klas, M., Bonani, G., and Wolfli, W. (1990). A salt oscillator in the Glacial Atlantic? The concept. Paleoceanography 5, 469-478.

Broecker, W. S., and Denton, G. (1989). The role of ocean-atmosphere reorganizations in glacial cycles. Geochimica et Cosmochimica Acta 53, $2465-2501$.

Clark, P. U., and Bartlein, P. J. (1995). Correlation of late Pleistocene glaciation in the western United States with North Atlantic Heinrich events. Geology 23, 483-486.

Gat, J. R. (1981). Lakes. In "'Stable Isotope Hydrology-Deuterium and Oxygen-18 in the Water Cycle" (J. A. R. Gonfiantini, Ed.), pp. 203221.

Grootes, P. M., Stuiver, M., White, J. W. C., Johnsen, S., and Jouzel, J. (1993). Comparison of oxygen isotope records from the GISP2 and GRIP Greenland ice cores. Nature 366, 552-554.

Grousset, F. E., Labeyrie, L., Sinko, J. A., Cremer, M., Bond, G., Duprat, J., Cortijo, E., and Huon, S. (1993). Patterns of ice-rafted detritus in the glacial North Atlantic. Paleoceanography 8, 175-192.

Gwiazda, R. H., Hemming, S. R., and Broecker, W. S. (1996). Provenance of icebergs during Heinrich event 3 and the contrast to their sources during other Heinrich episodes. Paleoceanography 11, 371-378.

Haskell, B. J., Johnson, T. C., and Showers, W. J. (1991). Fluctuations in deep western north Atlantic circulation on the Blake Outer Ridge during the last deglaciation. Paleoceanography 6, 291-312.

Heinrich, H. (1988). Origin and consequences of cyclic ice rafting in the northeast Atlantic Ocean during the past 130,000 years. Quaternary Research 29, 142-152.

Imbrie, J., Hays, J. D., Pisias, N. G., Prell, W. L., and Shackleton, N. J. (1984). The orbital theory of Pleistocene climate: Support from a revised chronology of the marine $\delta^{18} \mathrm{O}$ record. In "Mlankovitch and Climate, Part 1', (J. I. A. Berger, J. Hays, G. Kukla, and B. Saltzman, Eds.), pp. 269-305. Reidel, Dordrecht.

Keigwin, L. D., and Jones, G. A. (1989). Glacial-Holocene stratigraphy, 
chronology, and paleoceanographic observations on some north Atlantic sediment drifts. Deep Sea Research 36, 845-867.

Keigwin, L. D., and Jones, G. A. (1994). Western north Atlantic evidence for millennial-scale changes in ocean circulation and climate. Journal of Geophysical Research 96. [in press]

Kutzbach, J. E., and Guetter, P. J. (1986). The influence of changing orbital parameters and surface boundary conditions of climate simulations for the past 18,000 years. Journal of Atmospheric Science 43, 1726-1759.

Lajoie, K. R. (1968). "'Late Quaternary Stratigraphy and Geologic History of Mono Basin Eastern California."' Unpublished Ph.D. dissertation, University of California-Berkeley.

Lajoie, K. R., Robinson, S. W., Forester, R. M., and Bradbury, J. P. (1982). Rapid climatic cycles recorded in closed-basin lakes. 7th Biennial Conference, American Quaternary Association, Abstracts.

Lehman, S. J., and Keigwin, L. D. (1992). Sudden changes in north Atlantic circulation during the last deglaciation. Nature 356, 757-762.

Liddicoat, J. C. (1976). “A Paleomagnetic Study of Late Quaternary Dry Lake Sediments from the Western U.S. and Mexico." Unpublished Ph.D. dissertation, University of California-Santa Cruz.

Lund, S. P. (1993). Paleomagnetic secular variation. Council of Scientific Research Integration, Trivandrum, 423-438.

Lund, S. P. (1996). A comparison of Holocene paleomagnetic secular variation records from North America. Journal of Geophysical Research 101, $8007-8024$.

Lund, S. P., Liddicoat, J. C., Lajoie, K. R., Henyey, T. L., and Robinson, S. W. (1988). Paleomagnetic evidence for long-term $\left(10^{4}\right.$ year) memory and periodic behavior in the earth's core dynamo process. Geophysical Research Letters 15, 1101-1104.

MacAyeal, D. R. (1993). Binge/purge oscillations of the Laurentide Ice Sheet as a cause of North Atlantic's Heinrich events: Paleoceanography 8, 775-784.

Meese, D. A., Alley, R. B., Gow, A. J., Grootes, P. M., Mayewski, P. A., Ram, M., Taylor, K. C., Waddington, I. E., and Zielinski, G. A. (1994). Preliminary depth-age scale of the GISP2 ice core. CRREL Special Report 94-1, 66.

Negrini, R. M. (1997). Northwestern Great Basin lacustrine history In "Great Basin Aquatic System History." Unpublished abstract volume produced by the University of Utah, Salt Lake City, Utah.
O’Neil, J. R., Clayton, R. N., and Mayeda, T. K. (1969). Oxygen isotope fractionation in divalent metal carbonates. Journal of Chemical Physics 51, 5547-5558.

Pyke, C. B. (1972). Some meteorological aspects of the seasonal distribution of precipitation in the Western United States and Baja California. University of California Water Resources Center Contribution, 139.

Rind, D., Peteet, D., Broecker, W., McIntryre, A., and Ruddiman, W. (1986). The impact of cold north Atlantic sea surface temperatures on climate: Implications of the Younger Dryas cooling (11-10k). Climate Dynamics 1, 3-33.

Russell, I. C. (1889). Quaternary History of the Mono Valley, California. U.S. Geological Survey 8th Annual Report.

Schwartz, M., Lund, S. P., and Johnson, T. (1996a). Environmental factors as complicating influences in the recovery of quantitative geomagneticfield paleointensity estimates from sediments. Geophysical Research Letters 23, 2693-2696.

Schwartz, M., Lund, S. P., Glasscoe, M., and Liddicoat, J. (1996b). Normalized NRM intensity for 12-35 kybp from the Wilson Creek Beds, Mono Lake California. EOS 77, F169.

Starrett, L. G. (1949). The relation of precipitation patterns in North America to certain types of jet streams at the 300-millibar level. Journal of Meteorology 6, 347-352.

Stoner, J. S., Channall, J. E. T., and Hillaire-Marcel, C. (1996). The magnetic signature of rapidly deposited detrital layers from the deep Labrador Sea: Relationship to North Atlantic Heinrich layers. Paleoceanography 11, 309-325.

Stoner, J. S., Channell, J. E. T., and Hillarie-Marcel, C. (1995). Late Pleistocene relative geomagnetic paleointensity from the deep Labrador SeaRegional and Global correlations. Earth and Planetary Science Letters 134, 237-252.

Stuiver, M., Grootes, P. M., and Braziunas, T. F. (1995). The GISP ${ }^{18} \mathrm{O}$ climate record of the past 16,500 years and the role of the Sun, ocean, and volcanoes. Quaternary Research 44, 341-354.

Thompson, R. S., Benson, L. V., Hattori, E. M. (1986). A revised chronology for the last Pleistocene lake cycle in the central Lahontan basin Quaternary Research 25, 1-9.

Wahrhaftig, C., and Birman, J. H. (1965). The Quaternary of the Pacific mountain system. In "The Quaternary of the United States" (H. E. Wright, Jr. and D. G. Frey, Eds.), pp. 299-340. Princeton Univ. Press, New Jersey. 